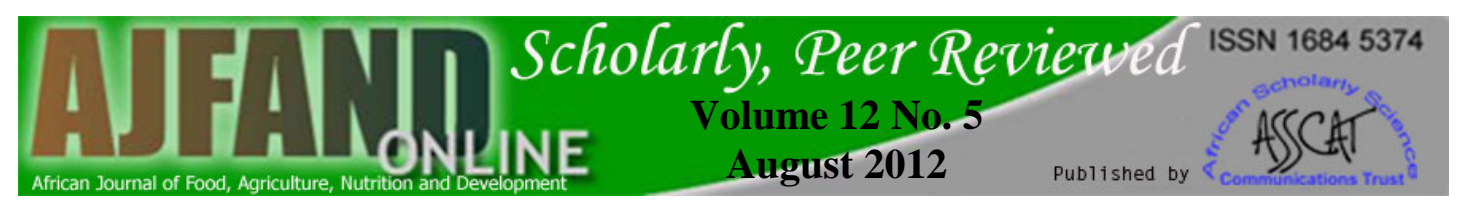

\title{
SOCIO-ECONOMIC DETERMINANTS OF CONSUMPTION PATTERN OF FISH AMONG HOUSEHOLDS IN IBADAN NORTH LOCAL GOVERNMENT AREA OF OYO STATE, NIGERIA
}

\author{
Adeniyi $\mathrm{OR}^{1^{*}}$, Omitoyin $\mathrm{SA}^{2}$ and $\mathrm{OO} \mathrm{Ojo}^{3}$
}

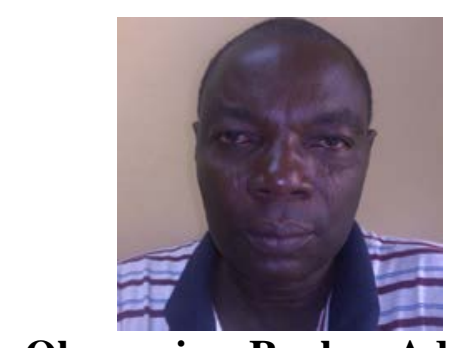

\section{Olawamiwa Reuben Adeniyi}

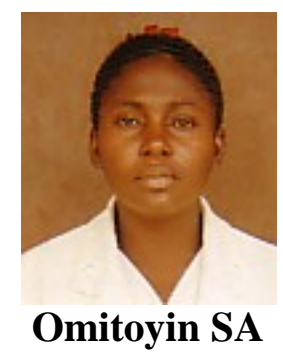

*Corresponding author email: adeniyiwamiwa2008@yahoo.com

${ }^{1}$ Production and Farm Management Economist, Senior Lecturer in the Department of Agricultural Economics and Extension Bowen University, Iwo, Osun State. Nigeria and formerly a Chief Lecturer in Adeyemi College of Education, Ondo, Ondo State, Nigeria

${ }^{2}$ Fisheries Economist, Lecturer I in the Department of Animal Science and Fisheries Management, Bowen University, Iwo, Osun State. Nigeria

${ }^{3}$ Graduate Student, Faculty of Agriculture, Bowen University, Iwo, Osun State, Nigeria. 


\section{ABSTRACT}

The importance of fish in meeting the nutritional requirements of the body for good health and a better standard of living cannot be overemphasized. The average consumption of protein in Nigeria is below 62 gm per day and a larger proportion of this is of plant origin. This has been found to be below the $70 \mathrm{gm}$ minimum recommended by the World Health Organization (WHO) and hence adequate consumption of fish would go a long way in correcting the protein intake shortfall. This research looked into the consumption pattern of fish among households in Ibadan North Local government Area of Oyo State, Nigeria. This is with a view to examining the various factors of social and economic importance affecting the level of consumption of fish and other protein foods in the study area. Stratified sampling technique was used to group the 12 wards in the study area into three. Structured questionnaires were used to collect information from the heads of the 40 randomly selected households in each of the three groups. Data collected from 100 fully completed questionnaires were analyzed using descriptive statistics, multiple regression and Chi-Square tests. The descriptive statistics result shows that majority of the consumers were male (67\%), with a mean age of 35.5 years. The mean amount of money spent on fish per month by the households was \$3, 672.60 (\$24.48). The regression result reveals that the total monthly expenditure on fish was positively affected by monthly expenditure on food and total monthly expenditure on animal protein. The coefficient of determination $\left(\mathrm{R}^{2}\right)$ of 0.682 implies that $68.2 \%$ of the variation in the household monthly expenditure on fish was explained by the variables in the regression model while the Chi-Square $\left(\mathrm{X}^{2}\right)$ calculated value of 77.7234 establishes the significant relationship between the respondents' income and their expenditure on fish. It is expected that with the potentials of wide acceptability of consumption of catfish, fish farmers should take advantage of the market, explore better means of increasing its production and add value to their product. There is also the need for survey on the current level of fish consumption at the states and national levels. This could assist in enhancing policy formulation to increase production, sustain and improve on the current level of consumption in order to reduce the incidence of nutrition-induced health problems particularly among the low income consumers in the society.

Key words: Consumption, Fish, Household, Expenditure, Nutrition-induced 


\section{INTRODUCTION}

Nigeria is faced with an acute nutrition problem, which is mostly due to inadequate food supply, poor income and lack of proper education on food selection. This problem leads to malnutrition, a consequence of unbalanced diet which in turn leads to poor physique and low energy output.

Protein for human consumption usually comes from plants and animals. Plant proteins are deficient in certain amino acids notably methionine, tryptophan and lysine which are necessary for proper healthy growth [1]. They are also relatively inferior to animal protein because protein quantity and quality differ widely at different parts as those obtained from root plants are not the same as ones from leafy plants. Some plant proteins have undesirable substances such as aflatoxin (as in groundnut seeds or peanuts, corn and tree nuts) which is said to cause liver cancer in poultry and man [2]. Animal protein is, however, rich in amino acids and is, therefore, described as first class or good quality protein [3]. This has informed a part of the reasons for the acceptability of animal protein..

However, the role of livestock and fishery industries as providers of animal protein rich in essential amino acids cannot be over-emphasized. Fish has low cholesterol compared with red meat and because of its ease of digestibility and soft tissue and its high nutritional value, it is highly recommended for both the young and the old [4].The fact that it is relatively cheap compared with meat, beef, mutton, poultry, pork, offal's and bush meat, which also contain protein of high biological value tends to make it preferred to other sources of animal protein [5]

The extent and depth of food insecurity in the developing world remains a big challenge. Out of about 800 million people of the developing world, one sixth is still found not to have sufficient food both in quantity and quality to live a healthy and productive life [6]. The tremendous decline in food production and supply brought about by the neglect of the agricultural sector as a result of the oil boom in the 1970's has a negative effect on the nutritional status of the Nigerian populace.

The low level of animal protein consumption in Nigeria as reported by the Food and Agriculture Organization (FAO) revealed that the diet of an average Nigerian contains about $20 \%$ less than the recommended requirement [7].This is no doubt responsible for most problems of malnutrition among all age groups particularly infants and children.

Fish consumption has undergone major changes in the past four decades. World apparent per capita fish consumption has been increasing steadily, from an average of $9.9 \mathrm{~kg}$ in the $1960 \mathrm{~s}$ to $11.5 \mathrm{~kg}$ in the $1970 \mathrm{~s}, 12.5 \mathrm{~kg}$ in the $1980 \mathrm{~s}, 14.4 \mathrm{~kg}$ in the $1990 \mathrm{~s}$ and reaching $16.4 \mathrm{~kg}$ in 2005 [8]

Fish provides quality easily absorbable protein and a wide variety of vitamins and minerals [8]. A small amount of fish is an important dietary supplement for poor people who cannot easily afford animal protein and who mainly rely on diets from

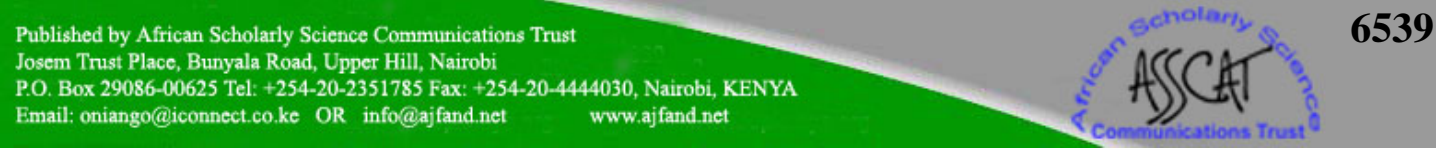


plant sources. Some studies have shown that people who eat fish about twice a day run a lower risk of heart attack than those people who rarely eat fish. The Omega-3fatty acids in fish oil are probably acting to reduce blood clotting which is part of heart attack process [6]. In some instances, fish oil capsules are safely substituted for fish consumption under physician's guidance.

One of the significant needs of protein on a world population basis is in infants after weaning and in young children. In instances where adequate protein and a proper diet are withheld for long, recovery may be incomplete due to irreversible damage and possible mental retardation.

A complete protein is said to have a high biological value when it contains all the essential amino acids that is adequate in amounts and proportions to maintain life and support growth. The protein in fish contains up to 22 of the essential amino acids in a well balanced ration. On the average, protein can supply 4kcal of energy per gram to the body; this can contribute significantly to energy needs in endurance exercise, perhaps as much as 10 to $15 \%$, especially as glycogen stored in the muscle is exhausted [1].

The extent to which Nigerians face the protein shortage problem calls for an urgent solution. In 1991, the Federal Ministry of Health indicated that malnutrition is the most serious health problem which directly hinders growth and development of the economy. This is because there is a great disparity between the required animal protein intake and the actual consumption. Most low income households assume that fish is meant for the adult members of the family; hence, nutrition problems still persist most especially among the young ones. Recent surveys show that one out of five persons is undernourished and that hunger, malnutrition and serious health problems are still inherent in many parts of Nigeria [9].

The total demand for fish was estimated at 1,150 million metric tones in 1979 and this increased to 1,450 million metric tones in 1988. Despite this increase, it was reported that the variation in demand with respect to supply was high. It has been reported that for a total consumption of 53.9 grams of protein, only 6.0-8.4grams per head per day was observed among Nigerians [10]. This falls short of Food and Agriculture Organization's minimum requirement of 65grams of protein and 2,500kcalories of energy per head per day [11].Out of the 800,000 metric tones demand, about 510,000 metric tones were produced locally leaving the deficit to be met by importation of frozen fish, canned and stock fish in spite of the huge drain on the economy. Hence, if adequate steps are taken to reduce the wide gap between demand and supply of fish, the food insecurity problem in Nigeria could be alleviated.

The main objective of this study is to determine the relationship between consumers' income and their expenditure on fish meal vis-à-vis the consumption pattern of fish among households in Ibadan North Local government Area of Oyo State. This is with a view to examining the various factors of social and economic importance affecting the level of consumption of fish and other protein meals in the study area. 
THEORETICAL FRAME-WORK: AN OVERVIEW OF FISH CONSUMPTION PATTERNS IN NIGERIA

Consumer behaviour is the study of how, when and why people buy what they buy. It attempts to explain the buyer decision-making process both individually and in groups. The theory of consumer behaviour assumes that a consumer is rational and aims at attaining the highest possible satisfaction given his income and the prevailing market prices. He attempts spending his income in a way that gives him maximum satisfaction [12].

An individual's decision on what range and type of food to consume is influenced greatly by income and other factors such as social norms. Various theories exist in literature that explain people's behaviour in relation to rising income. One of such is Professor Milton Friedman's permanent income hypothesis that consumption is based on the long run permanent income. It is only if people believed that a rise in today's income is likely to be sustained as higher future incomes will, that a large rise in current income will be matched by a large rise in current consumption.

The Life Cycle hypothesis held that households or individuals maximize their utilities subject to their wealth, the main determinants of current consumption and that the average long run income would likely determine the total demand for consumer spending. According to Engel law, the income elasticity on food consumption is low since with increasing income, people's spending on food decreases and a large percentage of additional income is committed to luxuries.

The life-style of people in urban cities is different from that of their counterparts in rural areas and this also influences to a considerable extent, their food consumption patterns. Most urban low income house-holds in Nigeria are plagued with inadequate animal protein intake due to lack of money to buy them [13], low level of income [14] and price of the commodity [15].

Promoting healthy diets and life-styles for individuals and population groups to reduce the global burden of non-communicable diseases requires a multipronged approach involving the various relevant sectors in the society. The agricultural and food sectors feature prominently and must be given due priority. Food strategies must not merely be directed at ensuring food security for all, but must also achieve the consumption of adequate quantities of safe and good quality food that together make up a healthy diet.

The global food fish supply and hence consumption has been growing at a rate of $3.6 \%$ per year since 1961, while the world's population has been expanding at $1.8 \%$ for the same period. The protein derived from fish, crustaceans and mollusks accounts for between $13.8 \%$ and $16.5 \%$ of the animal protein intake of the human population. The average apparent per capita consumption increased from about $9 \mathrm{~kg}$ per year in the early 1960's to $16 \mathrm{~kg}$ in 1977.The per capita availability of fish and fish product has, therefore, nearly doubled in 40 years outpacing population growth [16]. 
Fish contributed an increasing share of total protein intake until 1998 (accounting for between $6.5 \%$ and $8.5 \%$ ) but since then, its importance has gradually declined; and in 1997, its percentage contribution was back to the level prevailing in the mid-1980 [17].

Ighoro [18] in his study of the analysis of household consumption pattern of animal products in south-western Nigeria found out that the average monthly expenditure on fish was $34.885 \%$. Goat meat, chicken, pork, turkey, bush meat and mutton accounted for $4.3 \%, 5.23 \%, 4.6 \%, 4.13 \%, 3.4 \%$ and $1.05 \%$, respectively. Fish was reported to have the highest frequency of animal protein consumed by households. The Federal Department of Fisheries estimated per caput growth of fish consumption in Nigeria from $13.71 \mathrm{~kg}$ in 1993 to $14.49 \mathrm{~kg}$ in the year 2000 [19].

Akeson-Samson [20] reported that fish is the single most important animal protein consumed in almost all African countries. He, however, concluded that consumers usually have a natural preference for a particular fish species while acceptability may be influenced by taste, price and income of consumers. Adeyemi [21] on his own concluded that consumption of fish is a function of income.

In his own study, Adeosun [22]) emphasized that $70 \%$ of animal protein consumed by Nigerians comes from fish and he attributed the high demand and consumption of fish to improved standards in income levels, increased population and better health awareness while its relative cheapness compared with other suitable substitutes is also contributory [5]. In a similar vein, as observed in Britain, the variations in meat and fish consumption since 1960 are due to economic factors such as relative prices and expenditure and those factors which may be attributed to a shift in consumer preferences [23].

The impact that agricultural policies have on the structure of production, processing, distribution and ultimately on the availability of food that supports healthy food consumption patterns should not be overlooked. Household spending patterns reflect consumer life-style, disposable income, age, education and household size.

\section{RESEARCH METHODOLOGY}

The study was conducted in Ibadan North Local government Area of Oyo State. The choice of this distinct study area was due to the existence of inhabitants comprising people with a fair representation of different tribes existing in Nigeria, varying in categories of income levels (low, medium and high) and diverse occupations. Ibadan, a historic Yoruba town founded in 1820, is located in the tropical rain forest zone of Nigeria with a hot humid climate and an annual rainfall of 1.2 meters. Its geographical location makes it accessible. The nation's main sea-port and commercial centre, Lagos, is $131 \mathrm{Km}$ to the south while Abeokuta, an ancient major city in Nigeria is $77 \mathrm{Km}$ to the west of Ibadan. The city has an urban population of over 2 million people predominantly of Yoruba tribe with a sizeable proportion of major tribes of Hausa and Ibo and other minor tribes and ethnic groups in Nigeria. 
The main occupations of the indigenes are farming of food crops such as cassava, maize and vegetables; craft, trading, civil service and cottage industry. Major markets in the area include Beere, Gate, Bodija and Agbowo, which provide avenues for sale and purchase of fish, other meat and meat products and foodstuffs.

Ibadan North Local government Area is urban in all respects because it has a lot of modern social amenities, Federal and State government institutions, parastatals and non governmental establishments.

Data for the research study were obtained from primary and secondary sources through the use of a well-structured questionnaire schedule completed by respondents in the study area and from referenced publications. Stratified sampling technique was used to group the study area into three. This was done by dividing the 12 wards in the Local Government Area (LGA) into three groups of four each. Information on the number of households in each ward was obtained from the demography section of the state ministry of information located in Ibadan, the Headquarters. Simple random sampling technique was then used to select the households used as respondents. A total of 40 structured questionnaires were distributed to the household heads in each of the three groups consisting of four wards each to make 120 altogether. The questionnaire consisted of questions relating to the socio-economic background of the respondents, the level and amount of their income and the various forms of expenditure incurred on food, fish and other protein meals consumed by the households. Altogether, information from 100 fully completed and reliably cleaned questionnaires were used to obtain data used for this analysis.

Descriptive Statistics method was used to analyze the socio-economic characteristics of the respondents while Multiple Regression Analysis [24] was used to capture the factors that affect the consumption of fish using the Statistical package for Social Sciences (SPSS) Version 14.0 for Windows Evaluation software. The dependent variable was the total monthly expenditure of the households on fish consumed while the explanatory variables were the total monthly income, expenditures on food and animal protein, household size and level of education of household head. The ChiSquare $\left(X^{2}\right)$ test was used to test for the significance of the relationship between consumers' income and expenditure on fish consumption.

\section{RESULTS}

Table 1 presents the results on socio-economic characteristics of respondents in the study area. The result revealed that $49 \%$ of the households earned monthly income of up to $\$ 50,000(\$ 333.33)$ and about 35\% earned higher. Majority of the respondents spend up to $\$ 6,000$ (\$40.00) of their income on protein food. None of the respondents rated low, the importance of protein food in their daily meal and about $25 \%$ of them spend more than $\$ 2,000$ (\$13.33) per month on procuring animal protein foods. As much as $65 \%$, however, spend less than $\$ 4,000$ (\$26.67) on fish protein foods. About 16 percent of the households are either singles or had just married with or without a child and majority are having a family size of less than six altogether (82\%). This observation is a reflection of the literacy level of the respondents. In fact, 94 percent 
of them were literate of which 64 percent had post secondary school certificate. These are supposed to influence them positively in their attitude towards family planning. They are also expected to have positive attitudes towards the consumption of fish since they could understand the importance of feeding on good quality food such as fish protein.

Occupational distributions of the respondents revealed that majority of them (68\%) were self employed as artisans. Only 17 percent were civil servants while 15 percent are students. Among these groups, 40 percent either owned a homestead fish pond or rendered a helping hand in the distribution chain of the fish products in the study area.

The results of Regression analysis on the data are presented in Table 2.

The four functional forms, the Linear, Semi Log, Double Log and Exponential functions, used to estimate the consumption function were examined on the basis of the magnitude of regression coefficients, the significance of each consumption function as indicated by the " $t$ " and " $F$ " values, the magnitude of the coefficient of multiple determination $\left(\mathrm{R}^{2}\right)$ and the appropriateness of the sign of the regression coefficient to the a- priori expectations and also, based on economic theory.

Semi log form was found to be the best and therefore chosen as the lead equation used for this study. In a similar vein, Yemisi chose semi-log function as the "most appropriate" form when she examined food consumption patterns among University of Ibadan students [25].The semi log, lead equation, was significant at $1 \%$ level of probability with the coefficient of determination $\left(\mathrm{R}^{2}\right)$ of 0.682 . This implies that $68.2 \%$ of the variation in the household monthly expenditure on fish was explained by the variables in the regression model.

The explicit form of the lead equation is:

$$
\begin{array}{rlll}
Y= & -2352.88-671.723 X_{1}+1121.031 X_{2}+2093.966 X_{3}-264.007 X_{4}+871.029 X_{5} \\
& (-10.960) & (-1.261) & (3.791)
\end{array}
$$

Adjusted $\mathrm{R}^{2}=0.682$

$\mathrm{F}=40.317$

Out of the five explanatory variables captured in this study, the coefficients of the total monthly expenditure on food $\left(\mathrm{X}_{2}\right)$ and monthly expenditure on animal protein $\left(\mathrm{X}_{3}\right)$ were significant $(\mathrm{P} \leq 0.01)$ and positive. This means that these two variables exerted positive effects on the consumption of fish in the study area. It also implies that the proportion of funds that goes into expenditure of fish consumed out of the total monthly expenditure on food and animal protein is significantly high. The other variables were not statistically significant at any level even though the total monthly income $\left(\mathrm{X}_{1}\right)$ and household size $\left(\mathrm{X}_{4}\right)$ had negative relationship while the Educational levels $\left(\mathrm{X}_{5}\right)$ had a positive relationship with the total monthly expenditure on fish. 
Table 3 shows the Chi-Square test result on the relationship between house-hold income and their expenditure on fish. The hypothesis was tested at 5\% level of significance and gave a calculated Chi square value of 77.723 .

\section{DISCUSSION}

The modal age group (31-60 years) shows that majority of the fish consumers are in their active stage of working life either in self employment or in civil service. Fish meal is most ideal for the aged and the growing youth because of the ease of digestibility of its soft tissue [4]. The range of most respondents' monthly income is ( $\$ 15,000$ - $\$ 50,000$ ). This implies that majority of the respondents in the study area are capable financially to include fish meal in their diet if encouraged and well educated on the advantage of doing so, more so when it is the cheapest among other sources of animal protein [22]. However, expenditure on fish protein appeared to decrease with increasing income as only $15 \%$ of the $35 \%$ high income earner spends more than $\$ 6,000$ (\$40.00) on fish protein food per month. The implication is that, with increasing monthly income, people prefer other more costly sources of protein meal like beef, pork, poultry and snail and bush meats [25].

From the foregoing, it could be safe assuming that socio-economic characteristics of the population have a direct relationship with their consumption pattern. The concept of production function, known as Absolute Income Hypothesis, is generally recognized to be an invention of Keynes [26]. The concept made consumption to be dependent mainly on real income though he was perfectly aware that other factors besides income influences the level of consumption. Empirical evidence from the current study has shown that while income may be important, other personal factors of social and economic importance such as education, self ego, availability of substitutes, requirements of other financial needs and personal conviction also influence consumption.

Some other researchers $[27,28]$ have also concluded that apart from total income and/total expenditure, certain socio-economic factors such as educational level, household size and number of household members working, price of commodity, occupation, age and expenditure on other food and non-food items could influence household consumption behavior. An increase in the monthly expenditure on food, all things being equal, will increase the demand for fish since fish is a vital source of protein for households. With a unit increase in total monthly expenditure on food, the monthly expenditure on fish will increase by $\$ 1,121.03(\$ 7.47)$. Praise and Schweigert [3]) in their analysis of household expenditure pattern held that differences in consumption pattern of household can be ascribed to variation in disposable income between households and that any differences not explained could be due to non-economic factors such as the hydria concept of differences in taste.

From the statistical result, it could be inferred that as monthly expenditure on animal protein increases by one unit, expenditure on fish (Y) will increase by $\$ 2,093.97(\$ 13.96)$. This suggests that fish is an important source of animal protein consumed by households in Ibadan North LGA of Oyo State. Similar result was 
obtained in Ondo State of Nigeria when Fawusi reported a positive relationship between total expenditure on animal protein and fish meals [29].

The variables; total monthly income $\left(\mathrm{X}_{1}\right)$, household size $\left(\mathrm{X}_{4}\right)$ and Educational levels $\left(\mathrm{X}_{5}\right)$ were not statistically significant at any level even though the total monthly income and household size had negative relationships with monthly expenditure on fish. This is suggestive of the fact that with increase in income, there is every tendency that households would spend more on luxury goods and expensive sources of animal protein like beef, poultry, snail, bush meat and less on fish foods unless they are advised against such action. It has earlier been noted in Nigeria that expenditure elasticity is low for staple commodities such as coarse grains and tubers and high for high protein foods such as meat, fish and eggs, implying substitution of more expensive for less expensive food stuffs by the high-income groups [25]. Also, further increase in household size at the current level of income would worsen the food security status of households in the study area.

Atobatele and Aromolaran [30] estimated a regression equation of per caput protein intake on a number of socio-economic variables for consumption in Ibadan, Nigeria. The results showed that household income was a significant determinant of the level of daily per caput protein intake.

The educational level of respondents $\left(\mathrm{X}_{5}\right)$ had a positive relationship with the total monthly expenditure on fish. This could imply that improvement in the educational status of members of the households would expose them to more lucrative jobs and occupations with enhanced income hence more money to spend on quality diets of fish meal

The Chi-square value of 77.723 was significant for the relationship between the respondents' income and their expenditure on fish. This, compared with the earlier result of regression analysis which shows a negative relationship implies that should the current level of respondents income be increased, households may prefer spending on other luxuries in spite of their level of education [25]. The only solution that has the potentials for a rescue is intensive Nutritional education with active and dedicated supports by governments and non-governmental bodies and organizations.

\section{CONCLUSION}

The result of analysis in this survey showed that the animal protein sources popularly consumed among the respondents in Ibadan North Local Government Area are fish, turkey, beef and poultry products, with more preference for fish because of its affordable price. Results of statistical analysis indicated that the monthly expenditure on animal protein and monthly expenditure on food were the significant factors affecting fish consumption. Also, there was a significant relationship between the respondents' income and expenditure on fish. Therefore, for the current level of fish consumption in the study area to be sustained and improved upon, strategies towards boosting the production of fish both in the study area as well as at the national level should focus on creation of income-enhancing jobs and trainings through capacity

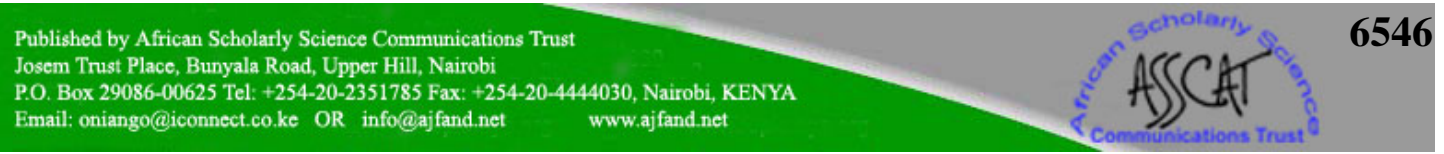




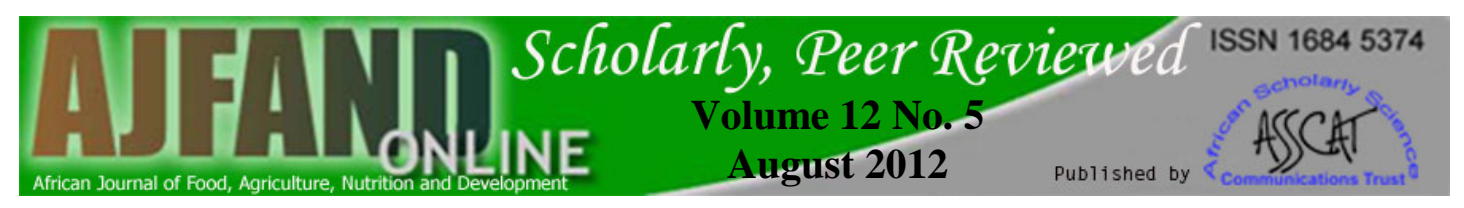

building in fish production and value addition to the products. These should be complemented with strategies of equitable income distribution and food and nutritional awareness programmes.

As household income increases, the importance of fish as a protein source in the diet should become more pronounced and increased for the much publicized, aggressive and far reaching awareness campaign currently in vogue by the government in the area of study on "Eat well to live well" to achieve its desired purposes. These will help reduce malnutrition and food insecurity problems, increase productivity among the populace and eventually lead to national development. 


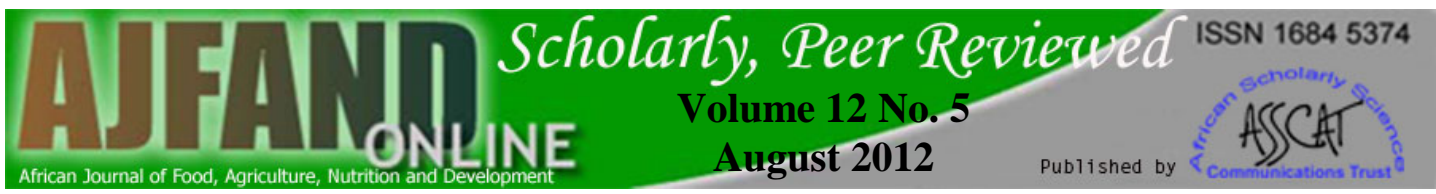

Table 1: Socio-economic characteristics of fish consumption household

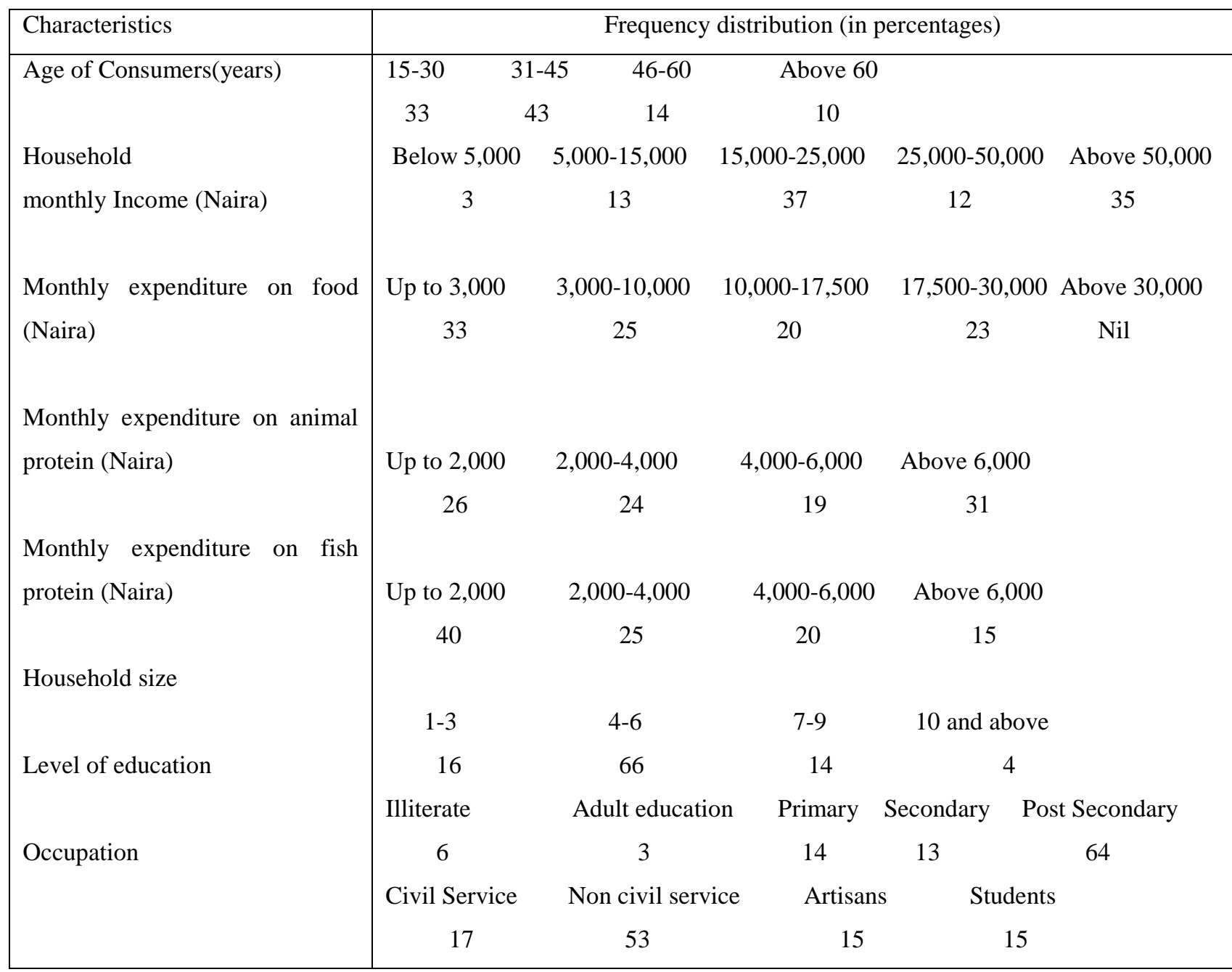

Source: Field survey 2008 and computations there from 
Table 2: Regression results on variables affecting consumption pattern of fish among Households

\begin{tabular}{|l|l|l|l|l|l|l|l|l|l|}
\hline $\begin{array}{l}\text { Functional } \\
\text { Form }\end{array}$ & $\mathrm{b}_{0}$ & $\mathrm{~b}_{1}$ & $\mathrm{~B}_{2}$ & $\mathrm{~b}_{3}$ & $\mathrm{~b}_{4}$ & $\mathrm{~b}_{5}$ & $\mathrm{R}^{2}$ & - & $\mathrm{F}$ \\
\hline Linear & -340.373 & -51.565 & 0.166 & 0.285 & -40.432 & 279.218 & 0.792 & 0.781 & 71.483 \\
$\mathrm{t}-$ value & $(-0.626)$ & $(-0515)$ & $(6.720)^{*}$ & $(7.287)^{*}$ & $(-0.616)$ & $(1.878)$ & & & \\
\hline Semi log & -2352.880 & -671.723 & 1121.031 & 2093.966 & -264.007 & 871.029 & 0.699 & 0.682 & 40.317 \\
$\mathrm{t}$-value & $(-10.960)$ & $(-1.261)$ & $(3.719)^{*}$ & $(8.135)^{*}$ & $(-1.032)$ & $(1.841)$ & & & \\
\hline Double log & 0.360 & 0.324 & 0.301 & 0.495 & $6.518 \mathrm{E} 03$ & 0.172 & 0.615 & 0.595 & 30.056 \\
$\mathrm{t}-$ value & $(0.454)$ & $(1.646)$ & $(2.755)^{*}$ & $(5.213)^{*}$ & $(0.069)$ & $(0.986)$ & & & \\
\hline Exponential & 6.202 & 0.149 & $3.359 \mathrm{E}-05$ & $5.286 \mathrm{E}-03$ & $4.872 \mathrm{E}-03$ & $7.222 \mathrm{E}-02$ & 0.572 & 0.549 & 25.131 \\
$\mathrm{t}-$ value & $(23.724)$ & $(3.083)^{*}$ & $(2.821)^{*}$ & $(0.154)$ & $(0.154)$ & $(1.010)$ & & & \\
\hline
\end{tabular}

Computed t-values in parenthesis

*coefficient significant at (1\%) level

$\mathrm{R}^{2}$ - Coefficient of Determination

$\mathrm{R}^{-2}$-Adjusted $\mathrm{R}^{2}$

$\mathrm{F}-\mathrm{F}$ Value

Table 3: Chi-Square test result on consumer's income and expenditure on fish consumed

\begin{tabular}{|l|c|c|c|}
\hline Items & Value & $\begin{array}{c}\text { Degree of freedom } \\
\text { (DF) }\end{array}$ & $\begin{array}{c}\text { Asymp. Sig. } \\
\text { (2 sided) }\end{array}$ \\
\hline Pearson Chi-Square & $77.723^{*}$ & 18 & 0.000 \\
\hline Likelihood Ratio & 87.126 & 18 & 0.000 \\
\hline $\begin{array}{l}\text { Linear-by-Linear } \\
\text { Association }\end{array}$ & 32.276 & 1 & 0.000 \\
\hline No of Valid Cases & 100 & & \\
\hline
\end{tabular}

*Significant at $5 \%$ level. 


\section{REFERENCES}

1. Cerny Frank J and Harold W Burton "Nutrition” Exercise Physiology for health care Professionals Edwards Brothers Printers/Publishers USA 2001:9-22.

2. Eraton DL and JD Groopman The Toxicology of Aflatoxins Academic Press New York 1994:383-426.

3. Praise JK and BSC Schweigert The Science of Meat and Meat Products. $W$. H. Freeman and Co., San Francisco, 1971; 287 pp.

4. Eyo AA Fish processing in the tropics. Published by National Institute for Fresh Water Fisheries Research (NIFER). 2002:1-4.

5. Adeniyi OR, Alabi OA and AA Ademosun Market Prices and Proximate Composition of Four Common Sources of Animal Protein in south-western Nigeria International Journal of Current Research 2010 ;9:062-064 http://www.journalcra.com Accessed February 9, 2011

6. FAO. Human nutrition in the developing world 1997 http://www.fao.org/docrep/W0073E/w0073e03.htm (Accessed January 10, 2009)

7. FAO. Statistical Data bases http://apps.fao.org/subscriber. 1992 (Accessed January10, 2009)

8. FAO. Fisheries-The State of World Fisheries and Aquaculture (SOFIA), 2008 PART 1: World review of fisheries and aquaculture; Fish consumption, p.5865.

9. Okunola OE "Household Consumption of Table Egg in Abeokuta Metropolis.” Unpublished B. Sc. Project Department of Agric. Economics, University of Ibadan, Ibadan. 2001

10. Lamode AG Household Food Consumption and Income Distribution Pattern in Nigeria. A Case Study of Ibadan Metropolis. Unpublished M. Sc. Thesis Department of Agric., Economics, University of Ibadan 2000.

11. FAO. Review of the State of the World Fishery Resources; Marine Fisheries. FAO fishery circular No 920 Rome. 1994.

12. Agbaje FI "Consumption preference and acceptability of some fresh water fishes in Abeokuta, Ogun State” Unpublished B. Sc. Project. Department of Fisheries and Aquaculture. University of Agriculture, Abeokuta, Ogun State. 2003.

13. Olayide SO Primer of Green Revolution in Nigeria. University of Ibadan Press, Ibadan Nigeria1990 
14. Adebayo OA Food Expenditure Pattern of Households in Ibadan B. Sc. Project Report Department of Agricultural Economics, University of Ibadan. 1990

15. Obayelu AE, Okoruwa VO and OIY Ajani "Cross-sectional analysis of food demand in the North Central, Nigeria: The quadratic almost ideal demand System (QAIDS) approach” China Agricultural Economic Review, Emerald Group Publishing Limited, 2009; 1(2):173-193

16. WHO. Global and Regional food Consumption Patterns and Trends: Availability and Consumption of Fish Nutrition Programmes and Projects 1998; http:www.whoint/nutrition/topics/3_foodconsumption/en/index5.html. Accessed 7 January 2011

17. Adeyemi ABO Food Consumption and Income Relationship in Nigeria: Engel's curve functions. Nigerian Economic and Social Studies, 2002;(1).

18. Ighoro GS Household Food Consumption and Income Distribution Pattern in Nigeria: A case study of Uyo Metropolis Unpublished M. Sc. Thesis Department of Agric Economics, University of Agriculture, Abeokuta 2002.

19. FDF. Aquaculture Development Research in Nigeria: In Aquaculture Development and Research in Sub-Sahara Africa. National Review GFA Technical paper, 223 Supplementary FAO, Rome 1982 :218-279.

20. Akesan-Samson Introduction to Aquaculture and Fisheries Management in Nigeria Published by Goad Educational Publisher. 2005:76p.

21. Adeyemi S Introduction to Aquaculture and Fisheries management in Nigeria: Criteria for selecting cultured species. Published by Goad Educational Publisher. 2005:22-23

22 Adeosun IO "Consumption pattern of fish among households in Offa, Kwara State”. M.Sc. Thesis, Department of Agric. Economics, Obafemi Awolowo University Ile-Ife. 2006

23. Popkin BM Nutrition in transition: The changing global nutrition challenge. Asian Pacific Journal of Clinical Nutrition 2001; 10 (Suppl)S13-S18.

24. Gujarati DN Basic Econometrics: $2^{\text {nd }}$ ed. McGraw-Hill Book Company, New York 1988; 431-466.

25. Yemisi SA Food Consumption Pattern among University of Ibadan Students, Nigeria. Journal of Science. 2004; 36 (2):229-236.

26. Keynes JM Book III: The Propensity to Consume in: The General Theory of Employment, Interest and Money.Marxists.org edition, London: Macmillan Cambridge University Press 2002 (Chaps 8, 9, 10). 


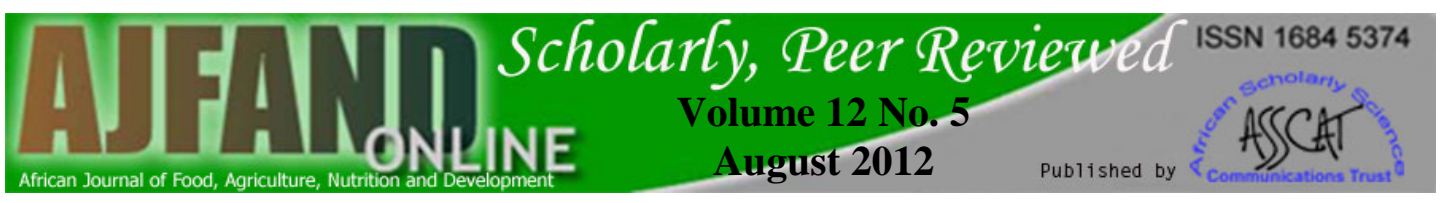

27. Davis CG Linkages between Socio Economic Characteristics, Food expenditure pattern and nutritional status of low income household: American Journal of Agric Economics 1982; 64:(5).

28. Izan HY and KW Clements A Cross-cross-sectional analysis of Consumption Patterns Economics Letters 1979; (4):83-86.

29. Fawusi AO Socio-Economic factors influencing food nutrient consumption of urban and rural households. A case study of Ondo State of Nigeria. Nigeria Journal of Nutritional Sciences. 1999; 6(3): 47-60.

30. Atobatele JT and AB Aromolaran Statistical analysis of the effect of demographic variables on the nutrition status of consumers in Ibadan city. Proceedings of the $12^{\text {th }}$ Annual Conference of the Nigerian Statistical Association1989. 